\title{
Design of a Performance-Adaptive PID Control System Based on Modeling Performance Assessment
}

\author{
Toru Yamamoto Member (Hiroshima University, yama@hiroshima-u.ac.jp)
}

Keywords: self-tuning control, PID control, control performance assessment, generalized minimum variance control, process control

Recently, the improvement of production quality and the reduction of the production cost have been further advanced in process industries represented by petroleum and refinery processes, and the control systems play an important role in such a situation. In Particular, the properties of process systems have been frequently changed due to the change of operating condition and/or nonlinearity of the systems. It is necessary to readjust the control parameters corresponding to the change of system properties in order to maintain the desired control performance. As one of such strategies, the self-tuning control has been proposed. Authors have also developed the self-tuning PID controller. However, according to the self-tuning controller, since the system parameters are recursively estimated and the controller parameters are adjusted based on the estimates, the computational burden and the reliability of the estimates have been pointed out in implementation to real systems.

By the way, for the purpose of maintaining the safety or the productivity of industrial processes, the researches on control performance assessment have been paid to attention in last decade. In process systems, it is necessary to specify the controller which does not give the satisfactory control performance, and to readjust control parameters included in the specified controller. In other words, it is most important problem to unify the control performance assessment and the controller design in industries.

In this paper, a design scheme of performance-adaptive PID controllers is newly proposed, which is shown in Fig. 1. According to the proposed control scheme, the modeling performance is firstly evaluated, and system parameters are identified, if the modeling performance is not good. In addition, PID parameters are adjusted based on the estimates so that the control performance satisfies the desired performance determined in advance.

The control result using the proposed control scheme for a time-varying system is shown in Fig. 2. For the purpose of comparison, the control result using the conventional selftuning PID control scheme is shown in Fig. 3. PID parameters are adequately adjusted corresponding to the system change, although the trajectories of PID parameters is omitted due to the page limit. From these results, it is clear that the proposed performance-adaptive PID controller works well for time-varying system.

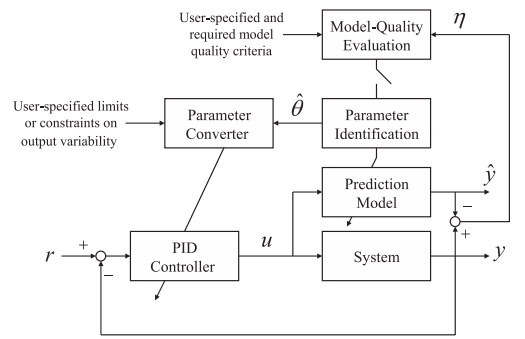

Fig. 1. Schematic figure of the proposed performanceadaptive PID control system
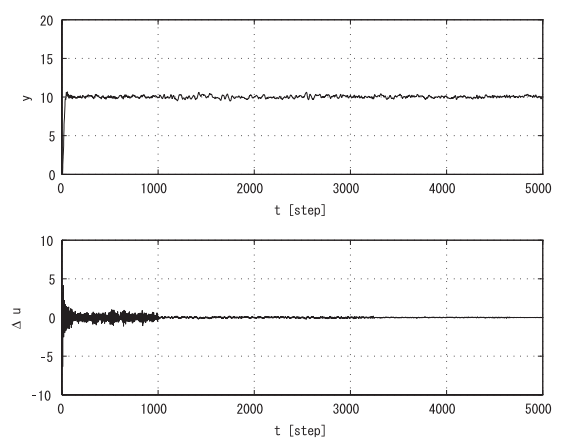

Fig. 2. Control result using the proposed control scheme
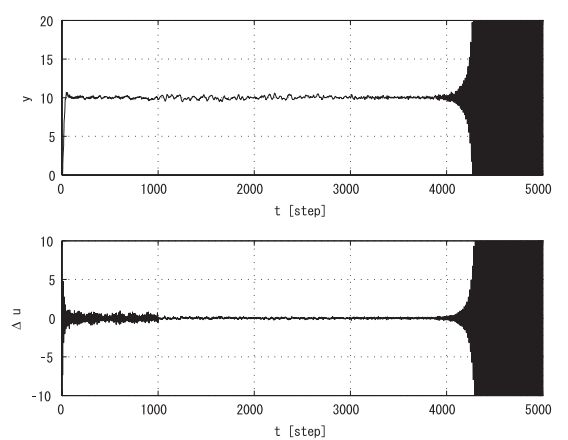

Fig. 3. Control result using the conventional selftuning PID control scheme 


\title{
モデリング性能評価に基づくパフォーマンス・アダプティブ PID 制御系の設計
}

\author{
正 員 山本 透* \\ Design of a Performance-Adaptive PID Control System \\ Based on Modeling Performance Assessment \\ Toru Yamamoto*, Member
}

\begin{abstract}
In industrial processes represented by petroleum and refinery processes, it is necessary to establish the performance-driven control strategy in order to improve the productivity, which the control performance is firstly evaluated, and the controller is reconstructed. This paper describes a design scheme of performanceadaptive PID controllers which are based on the above control mechanism. According to the proposed control scheme, the system identification works corresponding to the result of modeling performance assessment, and PID parameters are computed using the newly estimated system parameters. In calculating the PID parameters, the desired control performance is considered. The behaviour of the proposed control scheme is numerically examined in some simulation examples.
\end{abstract}

キーワード：セルフチューニング制御，PID 制御，制御性能評価，一般化最小分散制御，プロセス制御

Keywords: self-tuning control, PID control, control performance assessment, generalized minimum variance control, process control

\section{1. 緒言}

化学プロセスや石油精製プロセスに代表されるプロセス 産業界においては，国際競争の激化の煽りを受けて，生産 性の向上, 省エネルギー・省力化など, 品質向上と生産コ ストの低減が一層進められている。そのような現状におい て，制御システムが果たす役割もこれまで以上に重要視さ れてきている。とりわけ化学プロセスや石油精製プロセス などにおいては，操業条件の変更（製品銘柄の変更など）, 原料・環境の変化，あるいはシステムそのものがもつ非線形 性などにより，対象とするシステムの特性が変化すること が往々にして存在する。そのようなシステムに対して高精 度な制御性を得るためには，本来，システムの特性に対応 して制御システム（コントローラパラメータ）が自己調整 されることが望ましい。その一つのアプローチとして，セ ルフチューニング制御 ${ }^{(1)}$ があり，著者もこの考えに基づい たセルフチューニング PID 制御法 (1) (4) を提案している。 ところが，セルフチューニング制御法は，システムパラメー 夕を逐次推定し, その推定值に基づいてコントローラパラ

*広島大学大学院教育学研究科

干 739-8524 広島県東広島市鏡山 1-1-1

Graduate School of Education, Hiroshima University

1-1-1 kagamiyama, Higashi-Hiroshima, Hiroshima 739-8524
メータを調整する方式に基づいており, 計算コストやパラ メータ推定の信頼性における問題点が指摘され, 実用化の 大きな妨げとなっている。これを解決するためには，パラ メー夕同定法の抜本的な改良が望まれるところではあるが, 不必要なパラメー夕同定を回避することにより, 計算コス トの削減やパラメータ同定の信頼性を, 多少ではあるが向 上させることができると考えられる。

ところで，プロセス全体の安全性（安定性）の維持や，コ ントローラパラメータのチューニングが十分でない箇所を 特定することを目的として, 制御性能を操業データから評

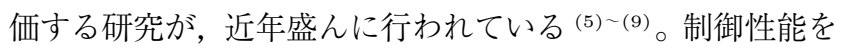
評価し, 制御性能が十分に発揮されていなければ, 所望の 制御性が得られるように制御パラメータを調整するといっ た一連のプロセスが, 実際の現場において必要とされてい る。この一連のプロセスを自動的に行うことが良いかどう かは別として,「評価」と「設計」を統合したアプローチは, 現在, 産業界における重要な課題の一つと考えられる。

そこで本論文では, モデリング性能を評価し, 評価が悪 い場合にシステム同定を行い, その推定值に基づいてコン トローラパラメータを調整する方法を提案する。このとき, コントローラパラメータの調整に際しては, 予め望ましい 制御性能を与え，これを満足するように調整する。具体的 には，著者が先に提案したセルフチューニング PID 制御 
法(4)を基盤にし，その方法に扔ける一つの設計パラメー夕 を，所望の制御性能が得られるように調整するものである。 所望の制御性能を保持することができるということで，本 論文で提案する制御法を，パフォーマンス・アダプティブ PID 制御法と呼ぶ。

\section{2. パフォーマンス・アダプティブ PID 制御系}

$\langle\mathbf{2} \cdot \mathbf{1}\rangle$ 制御系の概要セルフチューニング制御の基本 構成は，Åström らによって提案されたが，システムパラ メータを逐次推定し，その結果に基づいてコントローラパラ メータを調整する方式（Explicit 法）に基づいている ${ }^{(10) 。}$ 本方式の場合，パラメータ同定を逐次行うため, 計算コス トが大きい上に，パラメータ推定の信頼性にそしいことが 実装の大きな障害となっている。その一方で, 制御性能を 向上させる上では，システム同定は不可欠なものである。 このような状況から，本論文では以下のような観点に立っ たPIDコントローラを設計する。

(1)モデリング性能評価機構を設け，モデリング誤差が予め 設定した基準を超えたときのみパラメータ同定を行う。

(2)パラメータ同定を行った際は, その推定パラメータに

基づいて PID パラメータを変更する。

(3)PID パラメータの変更に際しては，制御性能（制御誤 差の分散と制御入力の差分の分散）を考慮する。

上述のように，常にPID パラメータを調整するのではな く, 予測誤差評価結果に基づいて, 必要に応じて PID パラ メー夕を変更するものである。本論文で提案するパフォー マンス・アダプティブ PID 制御系の概要図を Fig. 1 に示す。 ここで，本制御系を簡単に説明する。モデリング性能評価 機構 (Parameter Evaluation) において，モデル化誤差 $\eta$ と予め設定した基準值を比較し，これを超えた場合に，パラ メー夕同定機構（Parameter Identification）が機能し，新 しく予測モデルを更新するとともに，パラメータ変換機構 (Parameter Converter) において, 所望の制御性能 $\left(\sigma_{e}\right)$ を考慮して，パラメータ推定值 $\hat{\theta}$ に基づいて PID パラメー 夕を生成する制御系となっている。なお， $\gamma$ は，モデル化 誤差の基準值に相当するパラメータを示している。

$\langle\mathbf{2} \cdot \mathbf{2}\rangle$ システムの記述まず，制御系を設計する上で の記述モデルについて考察する。ここでは化学プロセスな どのプロセス系を対象とすることを考える。本来，化学プ ロセスは伝熱・対流・輻射などを考えれば高次遅れ系にな るが，システムパラメータの数が増えると，それだけ不確 かさを多く含むことになり，これが制御系設計に悪影響を 及ぼすことが考えられる。このような状況から，プロセス 系を扱う現場では，対象とするシステムを「一次遅れ十む だ時間」系として記述することが多く，ここでも次式を制 御対象の記述モデル（詳細モデル）とする。

$$
G(s)=\frac{K}{1+T s} e^{-L s} \ldots
$$

ここで， $K, T$, および $L$ は，それぞれシステムゲイン，時 定数，むだ時間を表している。

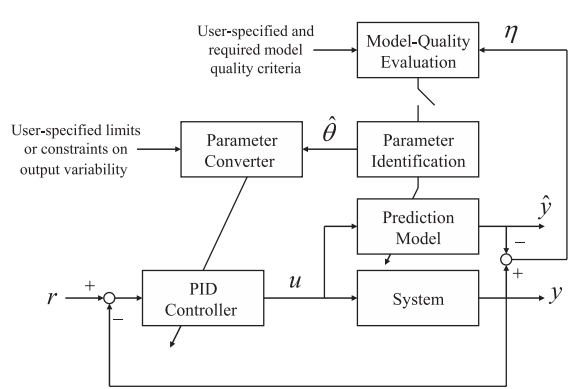

図 1 パフォーマンス・アダプティブ PID 制御系 の概要図

Fig. 1. Schematic figure of the proposed performanceadaptive PID control system.

さらに，むだ時間を一次パデイ近似し，次式のような二 次遅れ系（設計用モデル）を考える。

$$
G^{\prime}(s)=\frac{K\left(1-\frac{L}{2} s\right)}{(1+T s)\left(1+\frac{L}{2} s\right)} .
$$

むだ時間の有理式による近似は，むだ時間成分を陽にPID パラメータによって補償することを目的としている。

次に，(2) 式に対応した次式の離散時間モデルを考える。

$$
A\left(z^{-1}\right) y(t)=z^{-1} B\left(z^{-1}\right) u(t)+\chi(t) / \Delta
$$

ここで，

$$
\left.\begin{array}{l}
A\left(z^{-1}\right)=1+a_{1} z^{-1}+a_{2} z^{-2} \\
B\left(z^{-1}\right)=b_{0}+b_{1} z^{-1}
\end{array}\right\}
$$

であり, $u(t)$ は制御入力, $y(t)$ はシステム出力, ならびに $\chi(t)$ はモデル化誤差等を示すガウス性白色雑音である。ま た, $z^{-1}$ は時間遅れ演算子で, $z^{-1} y(t)=y(t-1)$ を意味し ている。 $\Delta$ は差分演算子を表しており, $\Delta:=1-z^{-1}$ で定義 される。(3) 式は CARIMA(Controlled Auto-Regressive and Integrated Moving Average) モデルであり，ステッ プ状の外乱や目標值点周りの定常項を除去する目的で，プ ロセス系に対して用いられている。

以上より，システムパラメー夕 $K, T$ ，および $L$ が与え られたとき，本論文では，これに基づいた (3) 式を用いて PID パラメータを算出する。

〈2・3 PID コントローラ 次式で与えられる PID （比例・微分先行型 PID）制御則を考える。

$$
\Delta u(t)=\frac{k_{p} \cdot T_{s}}{T_{I}} e(t)-k_{p}\left(\Delta+\frac{T_{D}}{T_{s}} \Delta^{2}\right) y(t)
$$

ただし， $k_{p}, T_{I}, T_{D}$ は，それぞれ比例ゲイン，積分時間， および微分時間を表しており, $e(t)$ は制御誤差で，次式で 与えられる。

$$
e(t):=r(t)-y(t)
$$

ここで， $r(t)$ はステップ状で与えられる目標值である。ま た， $T_{s}$ はサンプリング間隔である。目標值変更の際の制御 
入力のキッキングを回避する目的で，(5) 式の PID 制御則 を用いている。以下の考察を簡単にするために，(5) 式を 次式として書き換える。

$$
C\left(z^{-1}\right) y(t)+\Delta u(t)-C(1) r(t)=0 \cdots
$$

ただし，

$$
\begin{aligned}
C\left(z^{-1}\right):=k_{p} & \left\{\left(1+\frac{T_{s}}{T_{I}}+T_{D} T_{s}\right)-\left(1+\frac{2 T_{D}}{T_{s}}\right) z^{-1}\right. \\
& \left.+\frac{T_{D}}{T_{s}} z^{-2}\right\} \ldots \ldots \ldots \ldots \ldots \ldots
\end{aligned}
$$

$\mathrm{PID}$ 制御による制御性能は，(5) 式における PID パラメー 夕 $\left(k_{p}, T_{I}, T_{D}\right)$ に大きく左右される。ここでは, 制御性 能評価法との関連を考慮し, 著者が先に提案している一般 化最小分散制御（GMVC）(11) に基づいた PID パラメータ 調整法 $(\mathrm{GMV}-\mathrm{PID})$ (2) を用いる。次節において，本手 法を簡単に説明する。

〈2・4〉 PID パラメータの調整Ｃlarkeらによって提 案された GMVCの評価規範の一つの形が，次式として与 えられる(11)。

$$
J=E\left[\left\{P\left(z^{-1}\right) y(t+1)+\lambda \Delta u(t)-P(1) r(t)\right\}^{2}\right]
$$

ここで, $P\left(z^{-1}\right)$ は設計多項式であり，次式により設計する。

$$
\left.\begin{array}{l}
P\left(z^{-1}\right)=1+p_{1} z^{-1}+p_{2} z^{-2} \ldots \ldots \\
p_{1}=-2 e^{-\frac{\rho}{2 \mu}} \cos \left(\frac{\sqrt{4 \mu-1}}{2 \mu} \rho\right) \\
p_{2}=e^{-\frac{\rho}{\mu}} \\
\rho:=T_{s} / \sigma \\
\mu:=0.25(1-\delta)+0.51 \delta
\end{array}\right\}
$$

$\sigma$ は立ち上がり時間に相当するパラメータを示しており， $\mu$

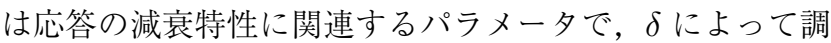
整される。このとき， $\delta=0$ は二項展開形式モデルに相当 する応答形状を示し， $\delta=1.0$ は Butterworth 形式モデル に相当する応答形状となる。一方， $\lambda$ は制御入力に対する

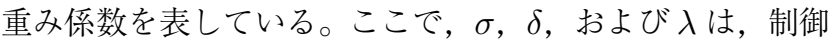
性（即応性，安定性，定常特性など）に大きな影響を与え る。設計の見通しを良くするために，事前情報から $\sigma$ は， 概ね時定数とむだ時間の総和の $1 / 3 \sim 1 / 2$ 程度に設定し， $\delta$ は，実用的観点から $0 \leq \delta \leq 2.0$ として設定する ${ }^{(2)}$ 。 $\lambda$ の みを，後で考察する方法によって調整するものとする。

(9) 式の評価規範の最小化により，次式による制御則が 与えられる。

$$
F\left(z^{-1}\right) y(t)+\left\{B\left(z^{-1}\right)+\lambda\right\} \Delta u(t)-r(t)=0
$$

ここで， $F\left(z^{-1}\right)$ は，以下の Diophantine 方程式に基づい て計算される。

$$
\begin{aligned}
& P\left(z^{-1}\right)=\Delta A\left(z^{-1}\right)+z^{-1} F\left(z^{-1}\right) \cdots \ldots \ldots \\
& F\left(z^{-1}\right)=f_{0}+f_{1} z^{-1}+f_{2} z^{-2} \ldots \ldots \ldots \ldots
\end{aligned}
$$

いま，(12) 式の第二項の係数多項式を定常項に置き換え た次式を考える。

$$
F\left(z^{-1}\right) y(t)+\{B(1)+\lambda\} \Delta u(t)-r(t)=0
$$

ここで，新しく $\nu$ を次式として定義すると，

$$
\nu:=B(1)+\lambda
$$

(15) 式は次式と書ける。

$$
\frac{F\left(z^{-1}\right)}{\nu} y(t)+\Delta u(t)-\frac{r(t)}{\nu}=0
$$

このとき，(7) 式と (17) 式を比較すると，

$$
C\left(z^{-1}\right)=F\left(z^{-1}\right) / \nu \text {. }
$$

として， $C\left(z^{-1}\right)$ を設計すれば，GMVC に基づいて PID パラメータを計算することができる。すなわち，(7) 式と (17) 式から，PID パラメータは次式により計算される。

$$
\left.\begin{array}{rl}
k_{p} & =-\frac{1}{\nu}\left(f_{1}+2 f_{2}\right) \\
T_{I} & =-\frac{f_{1}+2 f_{2}}{f_{0}+f_{1}+f_{2}} T_{s} \\
T_{D} & =-\frac{f_{2}}{f_{1}+2 f_{2}} T_{s}
\end{array}\right\}
$$

以上により，GMVC－PID を設計することができる。 なお，詳細は文献 $(2)$ を参照されたい。先にも述べたよう に，GMVCにおいてユーザが決定する設計パラメータ $\lambda$ を適切に設定することが非常に重要である。次節で考察す る制御性能評価との関連に基づいて，この設計パラメータ を設定することとする。

$\langle\mathbf{2} \cdot \mathbf{5}\rangle$ 制御性能評価に基づく $\boldsymbol{\lambda}$ の調整 制御性能を 評価する場合, 対象とするシステム（プロセス）によって, 評価方法が異なってくる。例えば，射出成型器や押出器の ような熱プロセスにおいては，同じ工程が繰り返され，そ の工程の速度が生産性に大きく影響する。したがって，こ のような場合は，即応性（目標值追従性）が要求される。一 方, 石油化学プロセスや石油精製プロセスにおいては, 過 渡状態はとにかく安定であることが大前提であり，定常特 性が生産性を大きく左右する。そのため即応性よりも定常 特性が重要視される。ここでは，後者の定常特性の評価に 焦点を絞って考察を進める。

定常特性の評価として, 文献 (5) では制御誤差の分散が 扱われている。具体的には，最小分散制御により実現され る制御誤差の分散を基準とした評価基準（ベンチマーク） が与えられている。生産性（例えば製品性状の均一化）を 向上させるためには, 制御誤差の分散を可能な限り小さく することが重要である。この意味において，本評価基準は， 


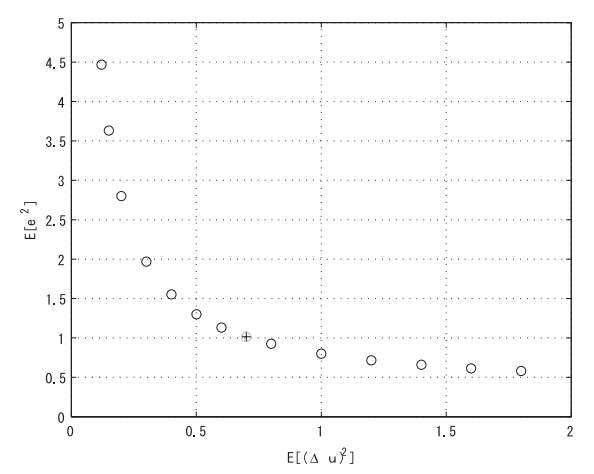

図 $2 \lambda$ を変化させたときの制御性能の変容 (Trade-off 曲線)

Fig. 2. Trade-off curve indicated by changing $\lambda$

有効な制御性能評価の目安となっている。しかし，その一 方で，もともと最小分散制御では，制御入力に何ら制約が 課せられていないために，制御入力の分散（あるいは，制御 入力の差分の分散）が大きくなり，実用面での問題が指摘 されている(7) (9)。化学プロセスに扔いては，生産性（製品 性状など）を向上させことが重要であるが，コスト削減，あ るいは省エネルギー化の問題も十分に考慮する必要がある。 したがって，ランニングコストを十分に抑えながら，生産 性を向上させることが最も重要であると考えられる。この ような理由から，制御誤差の分散と制御入力の分散（ある いは，制御入力の差分の分散）の双方を考慮した評価基準 が化学プロセスの制御性能評価として相応しく，これまで に，文献(7) (8)に扔いて考察されている。そこで，本論文 では, GMV - PID における入を, 制御誤差と制御入力の 差分の分散 (以降は, 簡単のために制御入力の分散という。) の双方に基づいて調整することを考える。GMV - PID に おいて，入を変化させたとき，Fig.2のような trade-off 曲 線 (6) (8) が得られる。縦軸は定常状態での制御誤差信号の分 散 $E\left[e^{2}(t)\right]$, 横軸は制御入力の分散 $E\left[(\Delta u(t))^{2}\right]$ を示して いる。

Fig.2 から明らかなように，入を変化させることで，制御 誤差の分散と入力の分散とが变化する。このとき， $\lambda$ の決 定が重要であるが，ここでは，制御誤差の分散をユーザが 指定し，それを満足する中で，制御入力の分散が小さくな るように，入を決定することを考える。ここでは，予め設 定した制御誤差の分散を 1.0 とすると, Fig. 2 で示す’+’の 点がこれに相当する。

〈2・6〉 システム同定セルフチューニングコントロー ラの設計に打いては, 通常, 逐次型最小 2 乗法を用いて, システムパラメータを逐次推定している。ここでも同様に, 逐次型最小 2 乗法を用いるが，パラメー夕同定の信頼性を 多少ではあるが向上させるために，以下の点を考慮する。

(1)予め設定したモデル化誤差の範囲を超えたときのみ， 現時刻から遡った $N$ ステップの入出力デー夕に対し て，逐次型最小 2 乗法を適用する。

(2)可能な限り推定するパラメータの個数を少なくする。
まず，(1) 式の詳細モデルに対応した次式の離散時間モ デルを考える。

$$
\alpha\left(z^{-1}\right) y(t)=z^{-(d+1)} \beta\left(z^{-1}\right) u(t)+\xi(t) / \Delta
$$

ただし，

$$
\left.\begin{array}{l}
\alpha\left(z^{-1}\right)=1+\alpha_{1} z^{-1} \\
\beta\left(z^{-1}\right)=\beta_{0}+\beta_{1} z^{-1}
\end{array}\right\} .
$$

ここで， $\xi(t)$ はモデル化誤差を示しており，平均 0 , 分 散 $\sigma_{\xi}^{2}$ のガウス性白色雑音とする。また， $d$ はむだ時間 を表している。通常, プロセス系ではむだ時間を正確に 把握することが難しく, この $d$ を予め想定される範囲内 $\left(d=d_{m}, d_{m}+1, \cdots, d_{M}\right)$ で順に変化させ, 推定誤差が最 も小さくなる $d$ を, むだ時間の推定值 $(\hat{d}(t))$ として決定す る。な㧍，(21) 式の $\alpha_{1}, \beta_{0}$, および $\beta_{1}$ は, 次式の逐次型 最小 2 乗法により推定する。

$$
\begin{aligned}
& \hat{\theta}(k)=\hat{\theta}(k-1) \\
& +\frac{\Gamma(k-1) \psi(k-1)}{1+\psi^{T}(k-1) \Gamma(k-1) \psi(k-1)} \varepsilon(k) \\
& \text {.............. } \\
& \Gamma(k)=\Gamma(k-1) \\
& -\frac{\Gamma(k-1) \psi(k-1) \psi^{T}(k-1) \Gamma(k-1)}{1+\psi^{T}(k-1) \Gamma(k-1) \psi(k-1)} \\
& \varepsilon(k):=\Delta y(k)-\hat{\theta}^{T}(k-1) \psi(k-1) \\
& \hat{\theta}(k):=\left[\hat{\alpha}_{1}(k), \hat{\beta}_{0}(k), \hat{\beta}_{1}(k)\right]^{T} \\
& \psi(k-1):=[-\Delta y(k-1), \Delta u(k-d-1), \\
& \Delta u(k-d-2)]^{T} \\
& k=t-N+1, t-N+2, \cdots, t-1, t \\
& =d_{m}, d_{m}+1, \cdots, d_{M}
\end{aligned}
$$

次に, システムパラメー夕の推定值 $(\hat{T}, \hat{K}, \hat{L})$ は, 次 式により計算する ${ }^{12)}$ 。

$$
\begin{aligned}
& \hat{T}(t)=-T_{s} / \log \left(-\hat{\alpha}_{1}(t)\right) \cdots \cdots \cdots \\
& \hat{K}(t)=\frac{\hat{\beta}_{0}(t)+\hat{\beta}_{1}(t)}{1+\hat{\alpha}_{1}(t)} \cdots \cdots \cdots \\
& \hat{L}(t)=\left\{\frac{\hat{\beta}_{1}(t)}{\hat{\beta}_{0}(t)+\hat{\beta}_{1}(t)}+\hat{d}(t)\right\} \cdot T_{s}
\end{aligned}
$$

〈2・7〉 パフォーマンス・アダプティブ PID コントロー ラこれまでに考察してきた個々の手続きを統合し，パ フォーマンス・アダプティブ PID コントローラを構築する。 そのアルゴリズムは以下の通りである。

$1^{\circ}$ ヒストリカルデータ（プロセスの操業データ）に基づ いて, 制御誤差の分散と制御入力の分散を計算する。 2 逐次型最小 2 乗法によりシステムパラメータを計算す る。また, 推定誤差 $\varepsilon(t)$ の標準偏差 $\sigma_{\varepsilon}$ を算出する。 
$3^{\circ}$ 推定パラメータを用いて， $\lambda$ を変化させて PID コント ローラ（GMV－PID）を設計する。このとき，それ ぞれの $\lambda$ に対応した制御誤差の分散 $\left(E\left[e^{2}(t)\right]\right)$ と制 御入力の分散 $\left(E\left[(\Delta u(t))^{2}\right]\right)$ を計算する。ただし，そ れぞれの分散の計算は， $H_{2}$ ノルムを用いて計算する (付録参照)。

$4^{\circ}$ 予め設定した制御誤差の分散 $\left(\sigma_{e}^{2}\right)$ を満足する中で, 制 御入力の分散が最も小さくなるポイントを算出し，こ れに対応する $\lambda$ ，ならびに PID パラメー夕を算出し， PID パラメータを変更する。

\section{$5^{\circ} t=t+1$}

$6^{\circ} 2^{\circ}$ で計算したシステムパラメータを用いて，次式によ り予測誤差 $\eta(t)$ を計算する。

$$
\eta(t):=\Delta y(t)-\hat{\theta}^{T}(t) \psi(t-1)
$$

ただし， $\hat{\theta}(t)$ と $\psi(t-1)$ は，(25) 式と $(26)$ 式と同様 の形で与えられる。

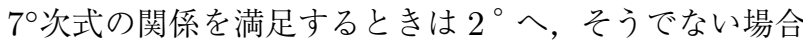
は，50へ戻る。

$$
|\eta(t)| \geq \gamma \sigma_{\varepsilon} \text {. }
$$

ここで, 最小二乗法のもつ性質から, 予測誤差が近似 的に正規分布に従うという前提において， $\gamma$ は統計的 観点から 3.0 5.0 程度を目安として設定する。

以上により，モデリング性能評価に基づいて PID パラ メータが調整されるパフォーマンス・アダプティブ PID コ ントローラを設計することができる。ここで，本提案手法 は，モデリング性能の評価基準（(31) 式）と PID パラメー 夕算出のための基準（(9) 式）の 2 つの基準を有している。 まず，モデリングが良好であるかどうかが (31) 式により評 価（判定）され，改めてシステム同定を行う場合は，(9) 式 の評価との関連に基づいて PID パラメータが算出されるこ とに注意されたい。なお， $1^{\circ} \sim 4^{\circ}$ の手続きは，PID パラ メータの初期チューニングの際にも利用することができる。

\section{3. 数 值 例}

本論文で提案したパフォーマンス・アダプティブ PID 制 御法の有效性を，数值例により定量的に評価する。

まず，PID パラメー夕の初期チューニングの際に本手法 を適用することを想定し，以下のような数值例を考える。 [例 1]

制御対象が次式で与えられるとする。

$$
G(s)=\frac{0.5}{1+100 s} e^{-45 s}
$$

(32) 式をサンプリング間隔 $T_{s}=10.0[\mathrm{~s}]$ で離散化し，モデ ル化誤差として平均 0 , 分散 0.001 のガウス性白色雑音を 付加したモデルを制御対象とする。

この制御対象に対して，提案手法を適用する。このときの 制御結果を, Fig.3に示す。ただし, 最初の 1000[step] にお いては, $k_{p}=3.56, T_{I}=100.0, T_{D}=49.5$ の PID パラ メータによる制御が行われており，その 1000 ステップ間の 入出力データを用いて, $t=1000[\mathrm{step}]$ の時点で, 先に示し
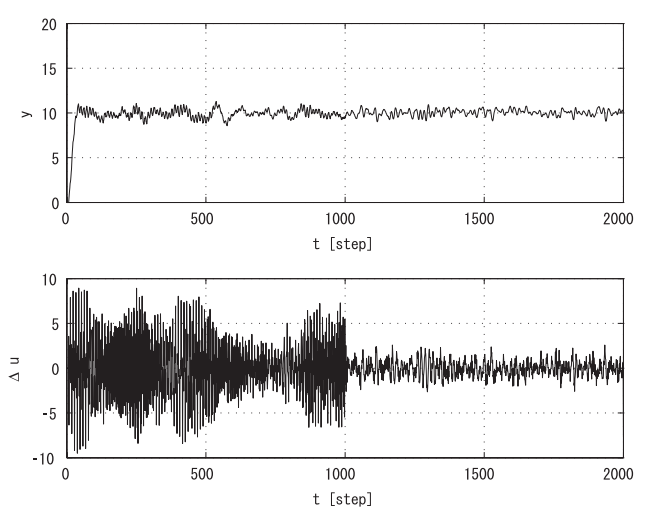

図 3 提案手法による制御結果 $\left(\sigma_{e}^{2}=0.09\right)$

Fig. 3. Control result using the proposed control scheme in the case of $\sigma_{e}^{2}=0.09$.

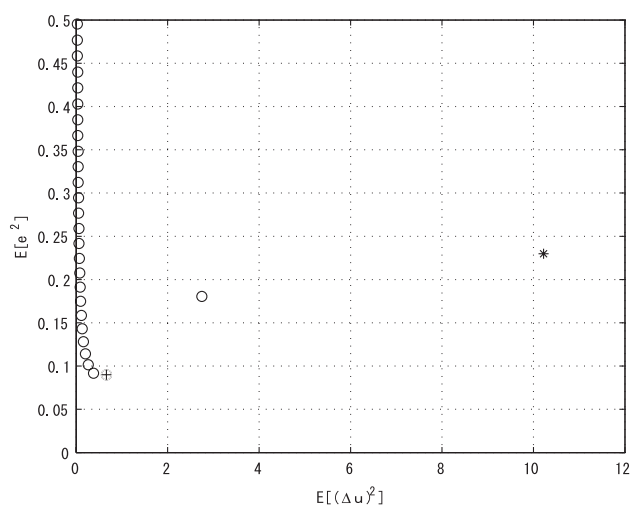

図 $4 \lambda$ を変化させたときの制御性能の変容 (Trade-off 曲線)

Fig. 4. Trade-off curve indicated by changing $\lambda$.

たアルゴリズムの $1^{\circ} \sim 4^{\circ}$ が適用されるものとする。なお， $d_{m}=4, d_{M}=8, \sigma_{e}^{2}=0.09, p_{1}=-1.53, p_{2}=0.59$ と設定した。また， $3^{\circ}$ に打いて， $\lambda$ は $0.0 \leq \lambda \leq 10.0$ の 間を， 0.01 刻みで変化させた。さらに， $t=1000$ における trade-off 曲線を Fig.4に示す。ただし, “*”印は最初の 1000 ステップにおける制御性能（制御誤差と制御入力の分散） を示している。また，'十'は，本アルゴリズムによって特定 した点（制御性能）を示している。このとき， $\lambda=0.05$ が 算出された。なお， $\lambda=0.0 \sim 0.03$ の間は制御系が不安定と なり，制御性能を計算することができなかった。 $\lambda=0.04$ に沶いては, 安定限界に近い応答を示しており, 制御誤差 の分散が大きくなっていることが分かる。

Fig. 3 と Fig.4より，提案手法を適用したことで，制御誤 差拉よび制御入力の双方が，効果的に抑えられていることが 分かる。なお， $t=1000$ [step] でのパラメー夕同定により， $\sigma_{\varepsilon}=0.0314, \hat{T}=99.22, \hat{K}=0.500, \hat{L}=50.00$ であり, 算出された PID パラメータは, $k_{p}=5.80, T_{I}=69.68$, および $T_{D}=15.88$ であった。さらに, 1500[step] から 2000 [step] 間の制御誤差の分散は, 0.1054 であり, 最初に 指定した望ましい制御誤差の分散 $\left(\sigma_{e}^{2}=0.09\right)$ に，概㸚近 い値となっている。 

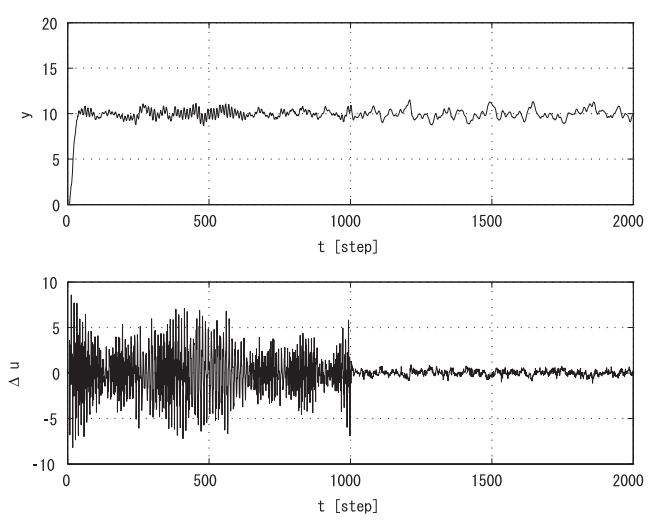

図 5 提案手法による制御結果 $\left(\sigma_{e}^{2}=0.25\right)$

Fig. 5. Control result using the proposed control scheme in the case of $\sigma_{e}^{2}=0.25$.

次に, 同様のシミュレーションを, $\sigma_{e}^{2}=0.25$ として行っ た結果を，Fig.5に示す。なお， $\sigma_{e}^{2}$ を除いた設計パラメー タは, 先と同じ值に設定した。

予め設定する $\sigma_{e}^{2}$ を大きくすると, 制御誤差の分散が大き くなり, 逆に trade-off 関係によって, 制御入力の分散が抑え られていることが分かる。なお，1500[step] から 2000[step] 間の制御誤差の分散は，0.2543 であり，設定した制御性能 が得られていることが分かる。なお，この場合の PID は， $k_{p}=2.44, T_{I}=69.13, T_{D}=15.84$ であった。 $T_{I}$ と $T_{D}$ は，先の結果とほぼ同じ值となっており，指定する制御性 能を変化させると $\lambda$ が変化し，それに対応して $k_{p}$ のみが 変化することが分かる。これは，(16) 式と (19) 式の関倸 からも明らかである。以上により，PID パラメータの初期 チューニングに扔ける, 提案手法の有効性が確認された。

次に, システムの特性が変動する場合を想定して, 以下 のような数值例について考察する。

[例 2]

対象とするシステムが，次式で与えられるものとする。

$$
G(s)=\frac{K}{1+T s} e^{-L s} \ldots \ldots \ldots \ldots \ldots \ldots \ldots
$$

ただし，2500[step] までは，[例 1] と同様の特性をもち， 2501[step] 以降 5000[step] まで, システムゲインと時定数 が以下のように変化し，むだ時間は変化しないものとする。

$$
\left.\begin{array}{l}
T=100-\frac{50(t-2500)}{2500} \\
K=0.5+\frac{2.5(t-2500)}{2500}
\end{array}\right\}
$$

時定数は最終的に $1 / 2$ 倍となり, システムゲインは 6 倍と なる。ここでも同様に，(33) 式をサンプリング間隔 $T_{s}=$ $10.0[\mathrm{~s}]$ で離散化し, モデル化誤差として平均 0 , 分散 0.0001 のガウス性白色雑音を付加したモデルを考える。

この制御対象に対して提案手法を適用する。ただし，最初 の 1000 [step] においては, [例 1] の場合と同様, $k_{p}=3.56$, $T_{I}=100.0, T_{D}=49.5$ の PID パラメータによる制御が 行われており，t=1000[step] 以降において，提案したパ
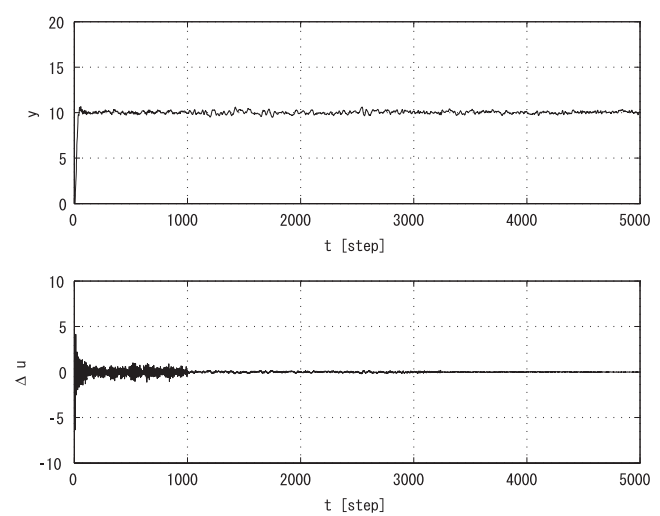

図 6 提案手法による制御結果 $(\gamma=3.0)$

Fig. 6. Control result using the proposed control scheme in the case of $\gamma=3.0$.
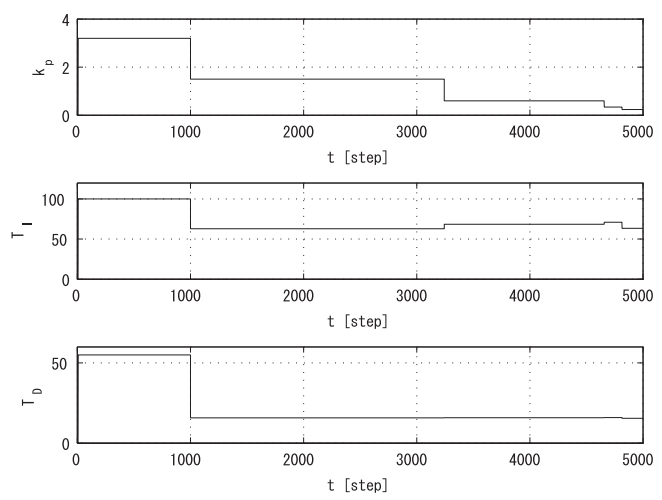

図 7 図 6 に対応したPID パラメータ調整結果

Fig. 7. Trajectories of PID parameters corresponding to Fig.6

フォーマンス・アダプティブ PID 制御法が適用される。なお， $d_{m}=4, d_{M}=8, \sigma_{e}^{2}=0.04, p_{1}=-1.53, p_{2}=0.59$ と 設定し， $3^{\circ}$ に扔ける $\lambda$ は，ここでも $0.0 \leq \lambda \leq 10.0$ の間 を，0.01刻みで変化させた。さらに， $7^{\circ}$ の $\gamma$ は 3.0 とし， パラメー夕同定に用いたデー夕数は， $N=200$ とした。こ のときの制御結果を Fig.6に，またPID パラメータの調 整結果を Fig.7 に示す。Fig.6 と Fig.7 から分かるように, $t=1000$ [step] での変更も含めて, 4 回の PID パラメー 夕調整が行われている。このとき， $\lambda$ は, $0.22(t=1500)$, $0.58(t=3243), 1.03(t=4657), 1.38(t=4814)$ と算出 された。なお，1000[step] 以降の制御誤差の分散は 0.0348 であり，予め設定した制御性能を発揮していた。この結果 より, システム変動に対して適切にPID パラメータが調整 され，良好な制御結果が得られていることが分かる。

次に, $7^{\circ}$ の $\gamma$ を 5.0 としたときの制御結果を Fig. 8 に，またそのときの PID パラメータ調整結果を Fig.9に 示す。 $\gamma$ を大きくしたことで, PID パラメータの調整が, $t=1000$ [step] と $t=3636$ [step] の 2 回のみであった。 $\lambda$ はそれぞれ，0.22 と 1.35 であった。1000[step] 以降の制御 誤差の分散は 0.0419 であり, 先に比べて性能が若干劣化す 

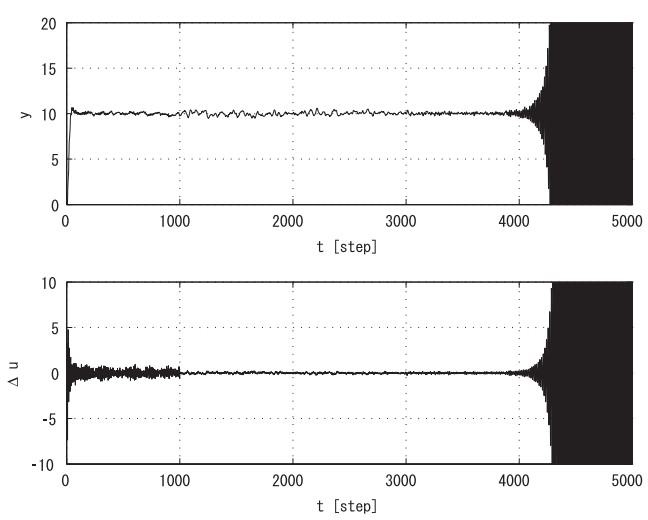

図 8 提案手法による制御結果 $(\gamma=5.0)$

Fig. 8. Control result using the proposed control scheme in the case of $\gamma=5.0$.
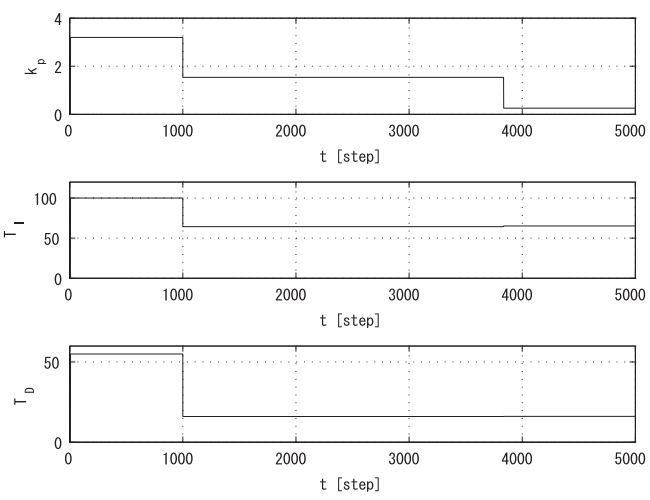

図 9 図 8 に対応したPID パラメー夕調整結果

Fig. 9. Trajectories of PID parameters corresponding to Fig.8

るものの，設定した制御性能を概ね満足している結果が得 られた。 $\gamma$ を変えることで，システム変動あるいはモデル 化誤差に対する感度を調整することができる。すなわち, を小さくすると感度が上がり，パラメー夕調整の頻度が増 加する。一方で， $\gamma$ を大きくすると感度が小さくなり，パ ラメータ調整の頻度は減少する。

最後に，比較のために，提案した手法の $1^{\circ} \sim 4^{\circ}$ のみを適 用した制御結果 $(\gamma=5.0)$ を Fig.10に，文献 (2) で提案し たセルフチューニング PID 制御法による制御結果を Fig.11 に示す。そのときの PID パラメー夕調整結果を Fig.12に 示す。なお，セルフチューニング PID 制御法はパラメータ 同定に基づいて，PID パラメー夕を逐次調整するものであ る。また，設計パラメータである $\lambda$ は， $\lambda=0.20$ として 固定し，逐次型最小 2 乗法には忘却係数を導入し，これを 0.98 とした。

まず，Fig,10においては，システム変動に対して PID パ ラメータを調整しなかったことにより，最後に制御系が不 安定に陥っている。これにより，オンラインでモデリング 性能を評価し, PID パラメー夕を変更することの有効性が 認められる。なお，1000[step] 以降の PID パラメータは, $k_{p}=1.9458, T_{I}=67.6249$, および $T_{D}=16.4162$ であっ
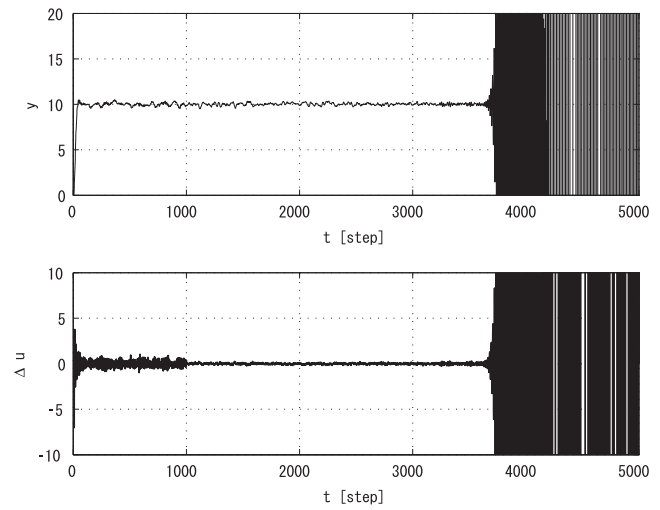

図 10 提案手法のうち $1^{\circ} \sim 4^{\circ}$ のみを適用した 制御結果

Fig. 10. Control result using the proposed control scheme where only the procedure from [step1] to [step4] is employed.
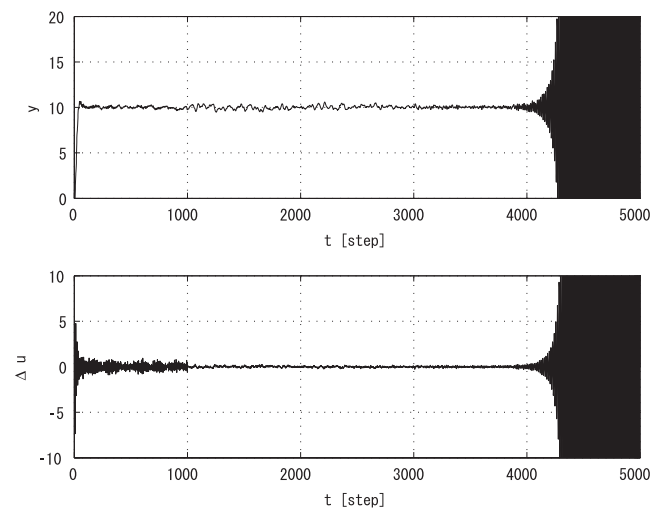

図 11 セルフチューニング PID 制御法による制 御結果

Fig. 11. Control result using the self-tuning PID control scheme.
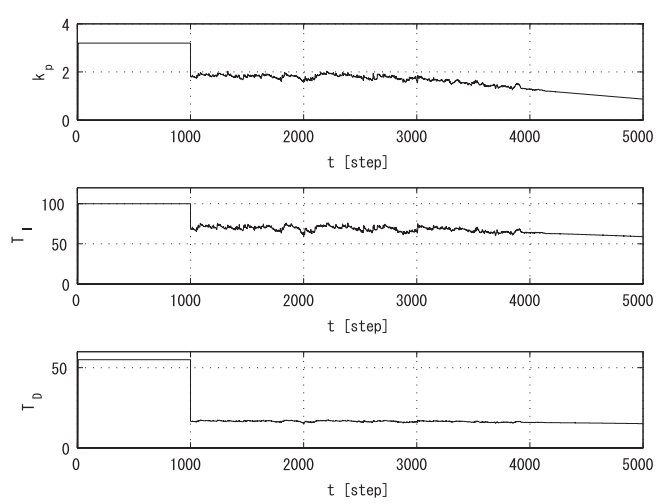

困 12 図 11 に対応したPID パラメータ調整結果

Fig. 12. Trajectories of PID parameters corresponding to Fig.11

た。一方，Fig.11では，オンラインでパラメー夕同定を行っ たものの，入を固定したことにより，制御性が保持されな いばかりか，この場合も最終的には不安定な制御系となっ 
ていることが分かる。また，PID パラメータが逐次調整さ れているために，微小ではあるが変化している。PID パラ メータを逐次調整すること，またそれにより PID パラメー 夕が变化することは，計算コストや信頼性の面で実装化の 大きな妨げとなる。この点に着目すれば，本論文で提案し たパフォーマンス・アダプティブ PID 制御法の有効性が顕 著に認められる。

\section{4. 結言}

本論文では, PID パラメータの調整法として，モデリン グ性能評価に駆動して PID パラメータを調整するパフォー マンス・アダプティブ PID 制御法を提案した。本手法の主 たる特徵は，以下のようにまとめられる。

(1)モデリング性能を評価し, この評価結果に基づいてシ ステム同定，ならびにPID パラメータ調整が行われる。

(2)予め設定した制御性能（制御誤差の分散）を実現する ように，可調整パラメータである入（制御入力項にか かる重み係数）が自動調整される。

(1)の特徵は, 必要に応じてシステム同定と PID パラメー 夕調整が行われることを意味しており, 従来法であるセル フチューニング PID 制御法に比べて, 計算コストならびに 信頼性の面で優れていると言える。一方，(2)の特徵は，制 御性能評価と制御系の再構築 (PID パラメー夕の再調整) を融合する，ひとつの形を示している。これにより,「Plan・ Do・See・Check」を一連とした制御システムを構築する ことができる。しかしながら，これまでのセルフチューニ ング PID 制御法と同様に，提案手法による制御性能が，パ ラメータ同定精度に大きく依存している。同定区間を設け たり，推定パラメータの数を極力減らすなどの工夫はした ものの，この点については本論文においても残されたまま となっている。これについては，今後の課題として，さら に考察を重ねる予定である。

最後に本研究は, 平成 $17 \cdot 18$ 年度日本学術振興会科学 研究費補助金基盤研究（B）（課題番号 17360199），ならび に平成 17 年度日本学術振興会特定国派遣プログラムの支 援を受けて行ったものである。とくに，特定国派遣プログ ラムにおいては, アルバータ大学 Sirish L. Shah 教授に有 益な助言を賜った。ここに記して感謝の意を表する。

(平成 18 年 9 月 19 日受付, 平成 19 年 5 月 7 日再受付)

\section{文献}

（1）大松 繁・山本 透編：「セルフチューニングコントロール」，コロ ナ社 (1996)

（2）山本 透·兼田雅弘:「一般化最小分散制御則に基づくセルフチューニ ング PID 制御器の一設計」, システム制御情報学会論文誌，Vol.11, No.1, pp.1-9 (1998)

(3) T. Yamamoto and S.L. Shah: "Design and Experimental Evaluation of a Multivariable Self-Tuning PID Controller", IEE Proc. of Control Theory and Applications, Vol.151, No.5, pp.645-652 (2004)

(4) 山本 透・藤井憲三:「実用化に向けたセルフチューニング制御系の 設計」, 電学論, 123-D, 9, pp.979-984 (2003-9)
(5) T.J. Harris: "Assessment of Closed Loop Performance", J. Canadian J. of Chemical Engineering, Vol.67, pp.856-861 (1989)

(6) B. Huang and S.L. Shah: "Performance Assessment of Control Loops: theory and applications", Springer-Verlag, London (1999)

( 7 ) M.J. Grimble: "Controller Performance Benchmarking and Tuning using Generalised Minimum Variance Control", $A u$ tomatica, Vol.38, pp.2111-2119 (2002)

(8) B. Huang: "A Pragmatic Approach Towards Assessment of Control Loop Performance", Int. J. of Adaptive Control and Signal Processing, Vol.17, pp.589-608 (2003)

（9）加納 学・山下善之：「プロセス制御系の制御性能評価と監視」, 計 測と制御, Vol.44, No.2, pp.125-129 (2005)

(10) K.J. Åström, U. Borisson, L. Ljung, and B. Wittenmark: "Theory and Applications of Self-Tuning Regulators", Automatica, Vol.13, No.5, pp.457-476 (1977)

11) D.W. Clarke and P.J. Gawthrop: "Self-tuning control", IEE Proc. of Control Theory and Applications, Vol.126, No.6, pp.633-640 (1979)

(12) R. Wood, S. Shah, R. Miller: "Adaptive Predictive Control Employing On-Line Time Delay Estimation", Advances in Instrumentation and Control (1995)

\section{付 録}

まず，定常状態において次式の関係を得る。

$$
\begin{aligned}
& e(t)=-\frac{1}{T\left(z^{-1}\right)} \xi(t) \cdots \\
& \Delta u(t)=-\frac{C\left(z^{-1}\right)}{T\left(z^{-1}\right)} \xi(t)
\end{aligned}
$$

ただし， $T\left(z^{-1}\right)$ は次式により定義される。

$$
T\left(z^{-1}\right):=\Delta \alpha\left(z^{-1}\right)+z^{-(d+1)} \beta\left(z^{-1}\right) C\left(z^{-1}\right)
$$

このとき, 制御誤差 $e(t)$ と制御入力 $\Delta u(t)$ の分散は, $H_{2}$ ノルム $\|\cdot\|_{2}$ を用いて，次式により計算することができる。

$$
\begin{aligned}
& E\left[e^{2}(t)\right]=\left\|-\frac{1}{T\left(z^{-1}\right)}\right\|_{2}^{2} \cdot \sigma_{\xi}^{2} \ldots \ldots \ldots \ldots \ldots \\
& E\left[(\Delta u(t))^{2}\right]=\left\|-\frac{C\left(z^{-1}\right)}{T\left(z^{-1}\right)}\right\|_{2}^{2} \cdot \sigma_{\xi}^{2} \ldots \ldots \ldots
\end{aligned}
$$

なお， $H_{2}$ ノルムはシステムパラメータの推定值とそれに基 づいて計算したPID パラメータを用いて計算する。また, 実際には， $\sigma_{\xi}$ は未知であるので，アルゴリズムの $2^{\circ}$ で算 出する $\sigma_{\varepsilon}$ に代えて計算する。

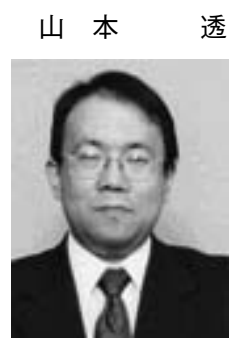

透（正員） 1961 年 8 月 29 日生。 1987 年 3 月徳島 大学大学院工学研究科修士課程 (情報工学専攻) 修了。大阪大学基礎工学部助手, 岡山県立大学情 報工学部助教授, 広島大学教育学部助教授などを 経て, 2005 年 4 月広島大学大学院教育学研究科 技術・情報教育学講座教授となり現在に至る。制 御系設計の高度化と知能化に関する研究に従事。 2006 年 3 月 9 月日本学術振興会特定国派遣研 究員 (アルバータ大学化学・材料工学科)。2003 年電気学会進歩賞, ならびに計測自動制御学会技術賞を受賞。工学博士。IEEE, 計測自 動制御学会，システム制御情報学会などの会員。 